\title{
Square Wave Voltammetric Determination of Dexamethasone on a Multiwalled Carbon Nanotube Modified Pencil Electrode
}

\author{
B. Rezaei, * S. Z. Mirahmadi Zare and Ali A. Ensafi \\ Department of Chemistry, Isfahan University of Technology, Isfahan, 84156-83111 I.R. Iran
}

\begin{abstract}
O comportamento eletroquímico de dexametasona, um hormônio esteroidal, foi estudado em um eletrodo de grafite modificado por nanotubos de carbono de camadas múltiplas, por voltametria de onda quadrada e espectroscopia de impedância eletroquímica. Dexametasona mostrou um pico de oxidação com potencial em torno de $+0,80 \mathrm{~V}$ na superfície do eletrodo modificado. Sob condições ótimas, a corrente de pico de oxidação depende da concentração da dexametasona e foi linear no intervalo de $0,15-100 \mu \mathrm{mol} \mathrm{L}^{-1}$ de dexametasona com um limite de detecção de $0,09 \mu \mathrm{mol} \mathrm{L} \mathrm{L}^{-1}$ de dexametasona. Os efeitos de substâncias interferentes potenciais na determinação de dexametasona foram investigados e encontrou-se que o sensor proposto é sensível e rápido para a determinação de dexametasona em produtos farmacêuticos e em amostras de urina humana sem qualquer tratamento prévio.
\end{abstract}

The electrochemical behavior of dexamethasone, a steroid hormone, was studied on a multiwalled carbon nanotube (MWCNTs) modified pencil electrode (PE) by square wave voltammety and electrochemical impedance spectroscopy (EIS). Dexamethasone showed one oxidation peak potential around $+0.80 \mathrm{~V}$ on the surface of the modified electrode. Under optimized conditions, the oxidation peak current depended on the dexamethasone concentration and was linear in the range of $0.15-100 \mu \mathrm{mol} \mathrm{L} \mathrm{L}^{-1}$ dexamethasone with a detection limit of $0.09 \mu \mathrm{mol} \mathrm{L}^{-1}$ dexamethasone. The effects of potential interfering substances on the determination of dexamethasone were investigated to find that the proposed sensor is a sensitive and fast tool for the determination of dexamethasone in both pharmaceutical and human urine samples without any pretreatment.

Keywords: multiwalled carbon nanotubes, dexamethasone, square wave voltammetry, impedance

\section{Introduction}

Dexamethasone (DXA) is a potent synthetic member of the glucocorticoid class of steroid hormones (Scheme 1). It acts as an anti-inflammatory and immunosuppressant agent. Dexamethasone acetate (DXA), dexamethasone sodium phosphate (DSP), and dexamethasone are derivatives of the adrenal corticosteroid group. They are broadly used to treat many inflammatory and autoimmune conditions (e.g., rheumatoid arthritis) and are useful to counteract the allergic anaphylactic shock. They are often administered before antibiotics in cases of bacterial meningitis to reduce the inflammatory response of the body to the bacteria killed by the antibiotics. Application of dexamethasone with alcohol, mineralocorticoids, oral antidiabetic drugs, insulin, certain

*e-mail: rezaei@cc.iut.ac.ir antibiotics, estrogens, ephedrine, and digoxin increases of side effect risks. Recently, abuse of adrenal corticosteroid in cosmetics has caused skin addiction and dermatitis has also been reported. ${ }^{1}$ The importance of controlling their therapeutic use and supervising its addition in animal food and cosmetics has warranted simple, sensitive, rapid, efficient, and practical methods to determine DXA, DSP, and dexamethasone in various samples. In addition, the therapeutic importance of dexamethasone required the development of sensitive and rapid methods for industrial quality control and clinical monitoring.

Various methods have been proposed for the analysis of DXA and other adrenal corticosteroid derivatives in different matrices. These methods are essentially based on separation methods such as liquid chromatography and HPLC-UV, ${ }^{2,3}$ thin-layer chromatography, ${ }^{4} \mathrm{LC}-\mathrm{MS},{ }^{5-7}$ LC-MS-MS, ${ }^{8}$ GC-MS with negative chemical ionization 


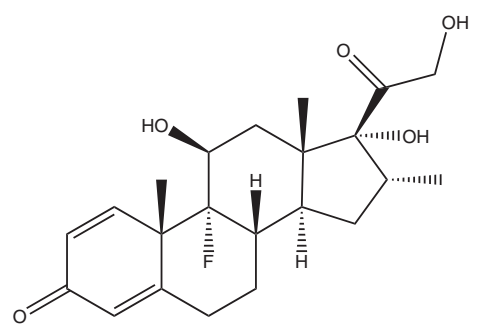

Scheme 1. Structure of dexamethasone.

source, ${ }^{9}$ HPLC-chemiluminescence, ${ }^{10-13}$ and finally flowinjection chemiluminescence method coupled with solvent extraction. ${ }^{14}$ Separation-detection methods such as GC-MS and HPLC-MS methods are expensive and time-consuming procedures, whereas the other separation methods suffer from such disadvantages as large amounts of high purity organic solvents required, long equilibration, and derivatization treatment. A few electrochemical papers have been published on the determination of dexamethasone based on reduction current, such as differential-pulse polarography ${ }_{1}^{15}$ and voltammetric methods using fullerene$\mathrm{C}_{60}$-modified pyrolytic graphite or modified carbon paste electrodes. ${ }^{16,17}$ Study of reduction current behavior of dexamethasone is difficult and limited to the use of mercury or specially modified electrodes. Many cations and organic substances could interfere with the reduction peak potential, especially at negative potentials. Also the mercury is very toxic and difficult to work so its application is limited. In this work, we used multiwalled carbon nanotubes to modify a pencil electrode to develop a sensitive, selective, and useful method for the determination of dexamethasone. This method is based on the unusual properties of carbon nanotubes such as strong adsorptive ability, huge specific area, subtle electronic properties, and excellent electrocatalytic activity. This work is the first reported on the electrochemical oxidation behavior of dexamethasone that is based on specific behavior of activated carbon nanotubes in electrocatalysis of dexamethasone oxidation. In addition, impedance spectroscopy was used to determine the oxidation mechanism of dexamethasone at the surface of the modified electrode.

\section{Experimental}

\section{Apparatus}

Voltammetric measurements were carried out using a Metrohm potentiostat/galvanostat (Model 797 VA), connected to a computer (Pentium IV, $1200 \mathrm{MHz}$ ) and with 797-VA computrace 1.2 Metrodata software. A conventional three-electrode system comprising a modified pencil electrode as a working electrode, a Pt-wire as an auxiliary electrode, and an $\mathrm{Ag} / \mathrm{AgCl}$ (saturated $\mathrm{KCl}$ ) reference electrode were used for the measurements.

Impedance measurements were performed with a conventional three-electrode cell, powered by an electrochemical system comprising the Autolab system (PGSTAT 12 and FRA2 boards, Eco Chemie B.V., Utrecht, and The Netherlands). The system was run on a PC using GPES and FRA 4.9 software. For impedance measurements, a frequency range of $100 \mathrm{kHz}$ to $10 \mathrm{~Hz}$ was employed. The AC voltage amplitude used was $5 \mathrm{mV}$, and the equilibrium time was $15 \mathrm{~s}$. The MWCNTs modified pencil electrode, a graphite electrode and a saturated $\mathrm{Ag} / \mathrm{AgCl}$ reference electrode were employed as a working, auxiliary and reference electrode, respectively.

\section{Chemicals}

All chemicals were of analytical reagent grade purchased from Merck (Darmstadt, Germany) unless otherwise stated. Deionized water of resistivity not less than $18.0 \mathrm{M} \Omega$ at $25^{\circ} \mathrm{C}$ was used throughout.

Dexamethasone was purchased from Aldrich. Dexamethasone ampoule $\left(2 \mathrm{mg} \mathrm{mL}^{-1}\right)$ was prepared from Amin Company (Tehran, Iran). Dexamethasone solution was prepared from $0.010 \mathrm{~mol} \mathrm{~L}^{-1}$ stock solution in deionized water.

Universal, acetate, phosphate and tris buffer (all $0.10 \mathrm{~mol} \mathrm{~L}^{-1}$ ) solutions with different $\mathrm{pH}$ values were used for the study of the $\mathrm{pH}$ influence.

MWCNTs was prepared from Irans Research Institute of Petroleum Industry with a diameter of 8-15 nm, a length of $50 \mu \mathrm{m}$ and the purity of $95 \%$. The modified electrodes with carbon nanotube layers were characterized by scanning electron microscopy (SEM) and 1578 B. energy dispersive X-ray (EDX) analysis.

Pencil core graphite (diameter equal to $0.5 \mathrm{~mm}$ ) from Micro was used for the preparation of the electrode.

\section{Preparation of the electrode}

To activate MWCNTs and to remove metal residuals in the nano-structure, $3.0 \mathrm{~g}$ of MWCNTs plus $20 \mathrm{~mL}$ of $3.0 \mathrm{~mol} \mathrm{~L}^{-1} \mathrm{HNO}_{3}$ were placed in a $25 \mathrm{~mL}$ flux and then refluxed for $15 \mathrm{~h}$. Then, the MWCNTs were washed with water and dried at room temperature. The stable suspension of activated MWCNTs was obtained by ultrasonicating of MWCNTs in dimethyl formaldehyde ( $0.10 \mathrm{mg}$ MWCNTs per $10 \mathrm{~mL}$ ). The surface of the pencil electrode (PE) was carefully polished onto a filter paper until it had a glossy appearance and then cleaned in an ethanol/water solution $(50 \% \mathrm{v} / \mathrm{v})$ in the ultrasonic bath. The cleaned PE was 
immerged in a stable MWCNT suspension for $1 \mathrm{~min}$ and dried in a hot air flow at $50{ }^{\circ} \mathrm{C}$. The two last steps were repeated for 20 times.

\section{Recommended procedure}

Ten $\mathrm{mL}$ of the buffer solution ( $\mathrm{pH}$ 5.0) were transferred into an electrochemical cell using a threeelectrode system containing the modified electrode as a working electrode. Then, square wave voltammogram (SWV) was recorded in the potential range of +0.40 to $+1.20 \mathrm{~V}$ with a frequency of $50 \mathrm{~Hz}$ and a potential step amplitude of $25 \mathrm{mV}$. The peak current was measured and recorded as a blank signal $\left(\mathrm{I}_{\mathrm{b}}\right)$. Once the background voltammogram was obtained, aliquots of the sample solution containing $5 \mathrm{~mL}$ of the buffer solution, $\mathrm{pH} 5.0$, plus a sufficient amount of dexamethasone solution was introduced into the cell. The SWV was recorded again in the potential range of +0.40 to $+1.20 \mathrm{~V}$ as described above to give the sample peak current. The peak current was measured and recorded as a sample signal $\left(I_{s}\right)$. The difference in current $\left(\mathrm{Ip}_{\mathrm{s}}-\mathrm{Ip}_{\mathrm{b}}\right)$ was considered as a net signal $\left(\Delta \mathrm{I}_{\mathrm{p}}\right)$ for each of the species. Calibration graph was prepared by plotting the net peak currents $v s$. dexamethasone concentrations in the solutions.

Urine and blood plasma samples were centrifuged (10000 rpm) to remove solid particles. Then, $1.0 \mathrm{~mL}$ of the sample solution plus $9.0 \mathrm{~mL}$ of $0.10 \mathrm{~mol} \mathrm{~L}^{-1}$ buffer ( $\mathrm{pH} 5.0$ ) were transferred into the cell to measure the dexamethasone contents using the standard addition method.

\section{Results and Discussion}

\section{Study of electrochemical behavior of dexamethasone}

The characterization of the MWCNTs film on the PE was investigated using the SEM method. ${ }^{18}$ It is obvious that the MWCNTs were distributed uniformly on the surface of the pencil electrode. The spaghetti-like MWCNTs formed a porous structure. The entangled cross-linked fibrils offered a highly accessible surface area. Similar observations have been reported in the literature. ${ }^{19}$

The voltammetric response of $2.5 \mu \mathrm{mol} \mathrm{\textrm {L } ^ { - 1 }}$ dexamethasone at the surface of bare and MWCNTsmodified electrodes at $\mathrm{pH} 4.0$ was recorded (Figure 1). The results confirm that the oxidation of dexamethasone on the surface of PE has a high overpotential. On the other hand, with the MWCNTs-modified electrode, the overpotential decreased sharply because of the activation of the surface of the modified electrode which proved the catalytic role of MWCNTs in dexamethasone oxidation. This clearly shows that dexamethasone does not have any oxidation peak on the bare PE that confirms previous reports about only reduction of dexamethasone on surface of carbon paste and glassy carbon electrode. On the other hand, the oxidation of dexamethasone occurred on the surface of MWCNTs-modified electrode at a potential near $0.90 \mathrm{~V}$ by elecrocatalytic effect of activated multiwalled carbon nanotubes.

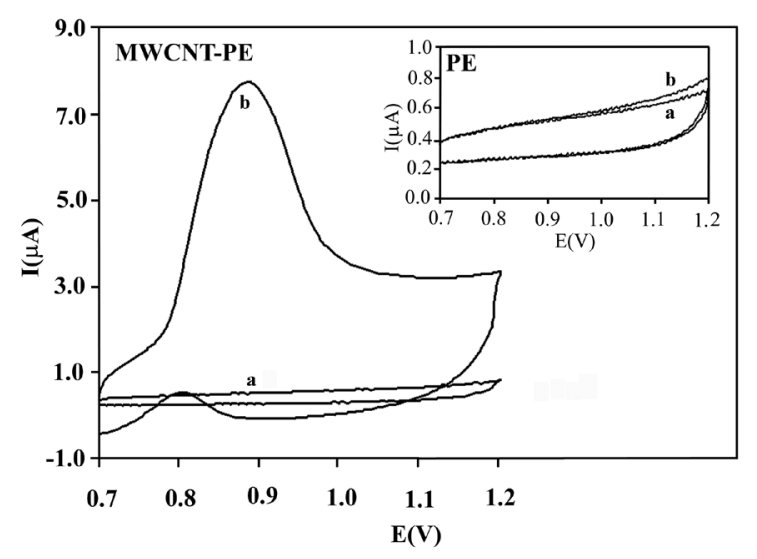

Figure 1. Voltammetric response of a) electrolyte and b) $1.0 \mu \mathrm{mol} \mathrm{L}-1$ dexamethasone on the bare (insert voltammogram) and MWCNTs modified electrode in $\mathrm{pH} 4.0$ acetate buffer.

\section{Influence of variables}

Buffer composition and $\mathrm{pH}$ are important parameters for the oxidation behavior of dexamethasone at the MWCNTs modified electrode. We, therefore, investigated the influence of buffer composition with identical $\mathrm{pH}$ values including acetate, universal, and phosphate solutions on the peak potential and current of dexamethasone. The results showed that the oxidation peak current of dexamethasone was maximized in the universal buffer as compared with the phosphate and acetate buffer solutions. Therefore, the universal buffer (containing $\mathrm{H}_{3} \mathrm{PO}_{4}, \mathrm{HBO}_{4}$, and acetic acid, $0.10 \mathrm{~mol} \mathrm{~L}^{-1}$ ) was selected for further study.

To find the optimum solution $\mathrm{pH}$, the influence of $\mathrm{pH}$ (between 2.0 to 8.0) on the peak current of $1.0 \mu \mathrm{mol} \mathrm{L} \mathrm{L}^{-1}$ dexamethasone was studied. Figure 2 shows that the peak potential and peak current of dexamethasone strongly depend on the $\mathrm{pH}$ of the solution. Our study showed that the oxidation peak of dexamethasone in an alkaline solution at $0.90 \mathrm{~V}$ fundamentally decomposed into three ill-defined oxidation peaks. When the solution $\mathrm{pH}$ was increased, it was observed that the peak potential shifted to less positive values and showed that the oxidation of dexamethasone is dependent on proton transfer. Based on this observation, dexamethasone can be said to be a multiproton donor and acceptor, which is in agreement with chemical structure of 
DXA. ${ }^{20}$ By treating MWCNTs in nitric acid, a carboxylic group is created on the surface of nanotubes. Therefore, the modified surface of MWCNTs will catalyze the proton transfer of dexamethasone oxidation and will decrease its oxidation potential. Under alkaline conditions, other sites of dexamethasone are activated so that new oxidation peaks appear. The relation of $\mathrm{E}_{\mathrm{p}}$ versus $\mathrm{pH}$ (in the $\mathrm{pH}$ range of 2.0-6.0) has a slope of $55.3 \mathrm{mV}$ versus $\mathrm{pH}$. This slope suggests that the number of electrons transferred is approximately equal to that of the hydrogen ions taking part in the electrode reaction. Finally, the alkaline solution was found not suitable for dexamethasone measurements; hence, a $\mathrm{pH}$ value of 5.0 was chosen as the optimum $\mathrm{pH}$ value with a high oxidation peak current.

The effects of frequency (affecting scan rate) on the SWV peak current and peak potential at MWCNTs modified electrode were investigated in the presence of $1.0 \mu \mathrm{mol} \mathrm{L}-1$ dexamethasone at pH 5.0 (Figure 2). The results showed that the anodic peak current increased linearly with increasing frequency according to the equation $\mathrm{I}(\mu \mathrm{A})=0.560 f(\mathrm{~Hz})+$ $3.993, \mathrm{R}^{2}=0.986$. This result indicates an adsorption controlled oxidation process occurring at the surface of the modified PE. ${ }^{21}$ Based on the results, a frequency of $50 \mathrm{~Hz}$ was selected as the optimum value for dexamethasone determination. The peak potential of dexamethasone was also found to shift to more positive potential values with increasing frequency. The plot of $\mathrm{E}_{\mathrm{P}}$ versus $\log f$ was linear with a correlation coefficient of 0.934 . Such a behavior indicates the reversible nature of the redox reaction. ${ }^{21}$ The variation of $\mathrm{E}_{\mathrm{P}}$ with $\log f$ can be expressed by the equation $\mathrm{E}_{\mathrm{p}}(\mathrm{mV})=51.40 \log f(\mathrm{~Hz})+881.1$.

The effect of amplitude voltage on peak current was studied in the range of $1-45 \mathrm{mV}$. It was found that the peak current increased sharply up to voltage amplitude of $30 \mathrm{mV}$, which tended to level off afterwards. So an amplitude voltage of $30 \mathrm{mV}$ was chosen as the best value for further study.

As already described, the influence of $\mathrm{pH}$ on peak potential showed that the current is dependent on the analyte adsorption at the surface of PE. Thus, the influence of accumulation potential (from 0.40 to $+0.90 \mathrm{~V}$ ) on the

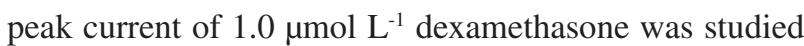
at the MWCNTs modified electrode using SWV with an accumulation time of $30 \mathrm{~s}$ at $\mathrm{pH} 5.0$ (Figure $3 \mathrm{a}$ ). The results showed that the accumulation time increases the oxidation peak current of dexamethasone but it is nearly independent
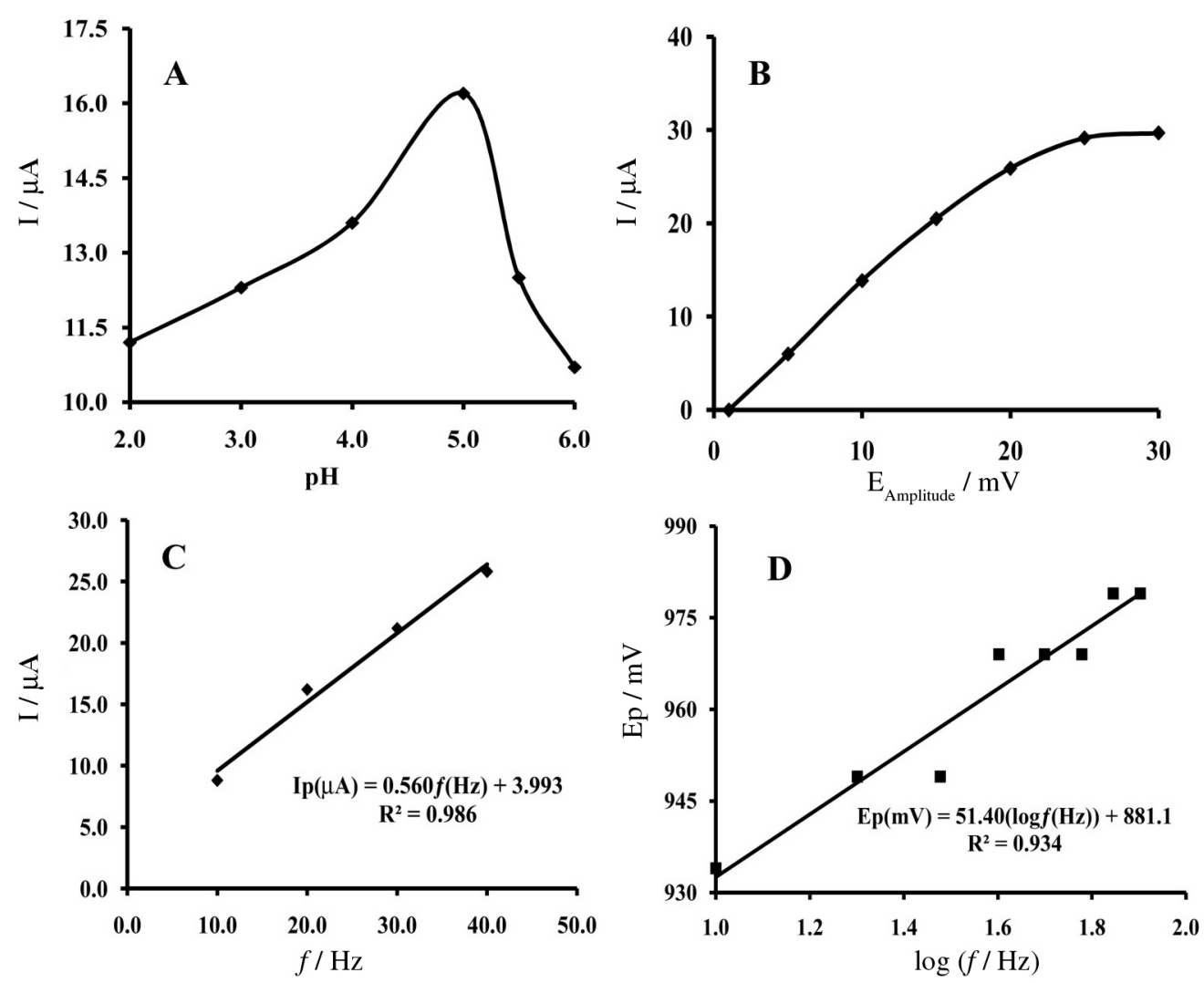

Figure 2. A) Current of $1.0 \mu \mathrm{mol} \mathrm{L}-1$ dexamethasone in $0.1 \mathrm{~mol} \mathrm{~L}^{-1}$ universal buffer solution at different pHs from 2.0 to 6.0 on the surface of the PE; B) peak current versus potential amplitude; C) peak current versus frequency; D) peak potential versus $\log f$ for $1.0 \mu \mathrm{mol} \mathrm{L}^{-1}$ dexamethasone in $0.1 \mathrm{~mol} \mathrm{~L}{ }^{-1}$ universal buffer solution at $\mathrm{pH}$ 5.0. 
of increasing accumulation potential up to $+0.80 \mathrm{~V}$, which subsequently decreased. This is due to the fact that beyond $+0.80 \mathrm{~V}$, the oxidation of dexamethasone occurred during accumulation. Hence, $+0.50 \mathrm{~V}$ was selected as the optimum accumulation potential.
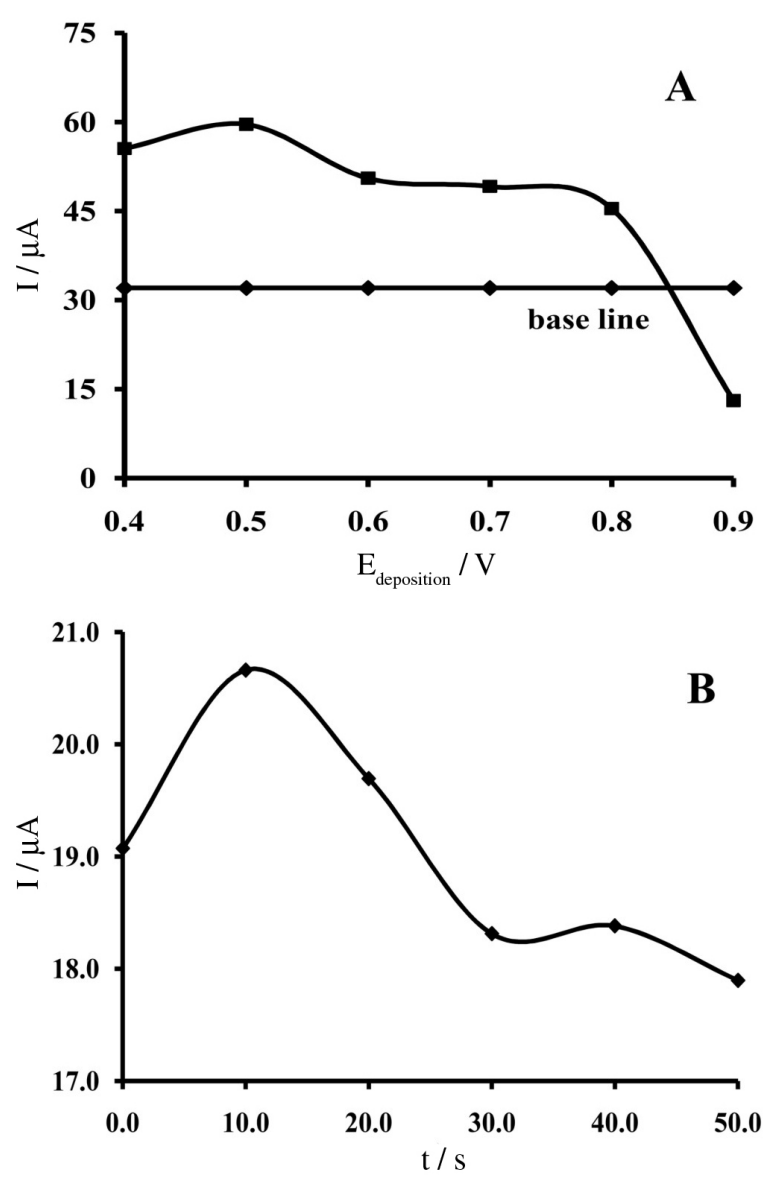

Figure 3. A) The oxidation peak currents of $1.0 \mu \mathrm{mol} \mathrm{L}-1$ dexamethasone after $30 \mathrm{~s}$ of accumulation at different potential from 0.40 to $0.90 \mathrm{~V}$ at $\mathrm{pH}$ 5.0 ; B) effect of accumulation time in accumulation potential on $0.50 \mathrm{~V}$.

The effect of accumulation time on peak currents with an accumulation potential of $+0.50 \mathrm{~V}$ for the oxidation of $1.0 \mu \mathrm{mol} \mathrm{L} \mathrm{L}^{-1}$ dexamethasone at $\mathrm{pH} 5.0$ was studied (Figure $3 b$ ). The results showed that increasing the accumulation time caused the peak current to increase. After $60 \mathrm{~s}$, it was leveled off due to adsorption saturation. Thus, $10 \mathrm{~s}$ was selected as the accumulation time.

Response time of electrode was examined by following chronoamperometry of $1.0 \mu \mathrm{mol} \mathrm{L} \mathrm{L}^{-1}$ dexamethasone at $\mathrm{pH} 5.0$, oxidation potential of $+0.80 \mathrm{~V}$ and duration time $5,10,15$ and $20 \mathrm{~s}$. The results show that the change in current after $10 \mathrm{~s}$ is less than $1 \%$. Also, it was mentioned that, the adsorption process of dexamethasone on surface of MWCNTs modified electrode after $60 \mathrm{~s}$ are saturated and current is leveled off.

\section{Electrochemical impedance spectroscopy}

Oxidation of dexamethasone on both PE and MWCNTs electrodes was investigated using the impedance spectroscopic method. Figure 4 shows the bode plot and the Nyquist plot of the impedance surface densities $\left(\Omega \mathrm{cm}^{-2}\right)$ and admittance surface densities $\left(\mathrm{S} \mathrm{cm}^{-2}\right)$ on the PE (A) and modified PE (B) electrodes recorded at $+0.60 \mathrm{~V}$ as DC offset for $1.0 \mu \mathrm{mol} \mathrm{L}{ }^{-1} \mathrm{DXA}$ at $\mathrm{pH}$ 5.0. Impedance and admittance quantities depend on the microscopic areas of the electrodes. The surface area of the bare PE and modified electrodes were different; therefore, the impedance elements were normalized after the experiments with respect to the electrode surface area during data analysis.

\section{Analytical performance}

Using square wave voltammetry and under the optimum conditions (selected as: $\mathrm{pH} 5.0$ (universal buffer) with a
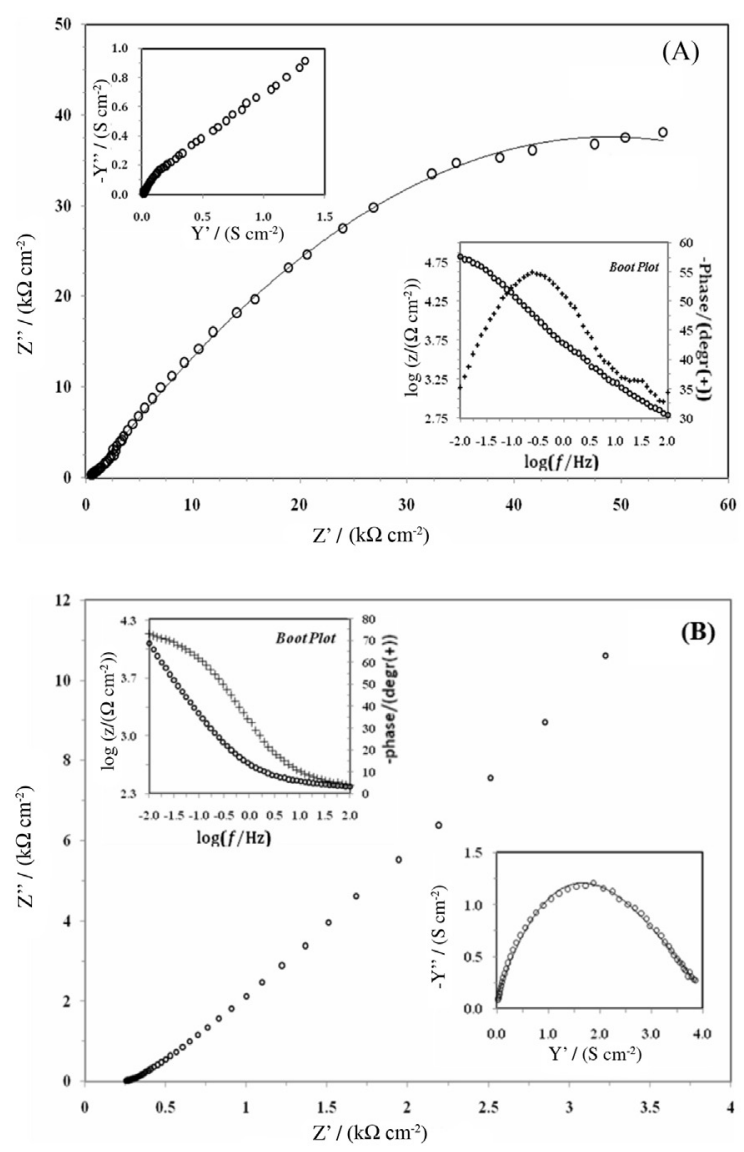

Figure 4. The Nyquist plots of the impedance surface densities $\left(\mathrm{Z}^{\prime \prime} \mathrm{cm}^{-2}\right.$ vs. Z' $\mathrm{cm}^{-2}$ ) acquired for $1.0 \mu \mathrm{mol} \mathrm{\textrm {L } ^ { - 1 }}$ dexamethasone in $\mathrm{pH} 5.0$ on the PE electrode (A) and MWCNTs modified electrode (B). Bias in both diagrams was $0.60 \mathrm{~V}$ with $5 \mathrm{mV}$ ac voltage amplitude and frequency range of $0.01 \mathrm{~Hz}$ to $100 \mathrm{kHz}$. Insets show their related a) bode plots and b) the admittance surface densities ( $\mathrm{Y}^{\prime} \mathrm{cm}^{-2}$ vs. $\mathrm{Y}^{\prime} \mathrm{cm}^{-2}$ ) plots. Points show the experimental data and the full line is calculated from the fitted parameters. 
frequency of $50 \mathrm{~Hz}$ and a potential amplitude of $30 \mathrm{mV}$ ), the calibration plot of dexamethasone determination was linear over a concentration range of $0.15-100 \mu \mathrm{mol} \mathrm{L}^{-1}$ with a regression equation of $\mathrm{I}(\mu \mathrm{A})=0.122 \mathrm{C}_{\mathrm{DXA}}+1.470$ $\left(\mathrm{R}^{2}=0.9991\right)$ (Figure 5).

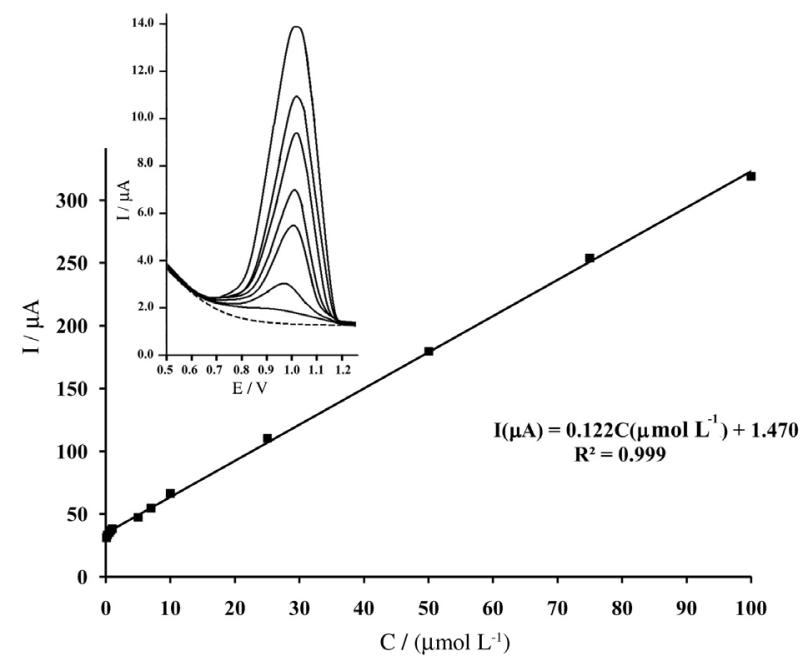

Figure 5. Calibration curve of dexamethasone at $\mathrm{pH} 5.0$ with frequency of $50 \mathrm{~Hz}$, pulse amplitude of $25 \mathrm{mV}$ and with $10 \mathrm{~s}$ accumulation potential at $0.50 \mathrm{~V}$.

The detection limit, defined as the blank signal plus three times its standard deviation, was $0.090 \mu \mathrm{mol} \mathrm{L}^{-1}$ dexamethasone. The relative standard deviation $(\mathrm{RSD} \%)$ is less than $1 \%$ for $2.5 \mu \mathrm{mol} \mathrm{L}-1$ dexamethasone (for five analysis), which shows excellent reproducibility.

The stability of the modified electrode was good. No obvious changes were observed in the peak currents for the same sample concentration after several runs of the SWV when the modified electrode was kept at a room temperature of about $25^{\circ} \mathrm{C}$ for one month. In fact, the performance of the modified electrode completely depends on the yield of surface modification with MWCNTs. Furthermore, electrode preparation is a critical measurement step. But the preparation procedure is repeatable which is confirmed by using of F-test to comparison of standard deviation of determination of DXA in 5 days electrode preparation. The results show that there is no significant difference between different days preparation electrode. So the repeatability of electrode like its reproducibility is good. The figures of merit of dexamethasone determination with the sensor were compared with other electrochemical methods reported as given in Table 1. In this table it is obvious that MWCNTs modified PE based on its specific design is the only one to show an oxidation behavior for dexamethasone in lower potential in relation to other electrodes (hanging mercury electrode and modified graphite electrode). Also this new electrode linear dynamic range is three orders of magnitude better with regard to other electrodes with one, ${ }^{15}$ or two, ${ }^{16,22}$ orders of magnitude. As well, proposed electrode without any preliminary stripping step has good detection limit in comparison to other electrodes, only long time stripping on hanging mercury electrode has shown lower detection limit. ${ }^{22}$ In addition, MWCNTs modified pencil electrode in comparison to mercury electrode is safe and easy to work and can be used for analysis of different pharmaceutical samples.

\section{Interference study}

Under the optimized experimental conditions described above, the effects of some ordinary compounds in biological media and drugs typically used with dexamethasone were investigated using $1.0 \mu \mathrm{mol} \mathrm{L} \mathrm{L}^{-1}$ dexamethasone. The tolerance limit was defined as the maximum concentration of the substance that caused an error of less than $3 \%$ in dexamethasone determination. The results in Table 2 show that common cations and anions do not affect dexamethasone determination, but some related pharmaceutical compounds have similar responses and, hence, interfere with the dexamethasone signal.

\section{Analytical application}

To evaluate the applicability of the proposed method, the recovery of dexamethasone was determined in common

Table 1. Analytical parameters of several electroanalytical methods used to dexamethasone determination

\begin{tabular}{lccccc}
\hline Method & $\mathrm{E}_{\mathrm{p}} / \mathrm{V}$ & Electrode & $\begin{array}{c}\text { Limit of detection / } \\
\left.(\mu \mathrm{mol} \mathrm{L})^{-1}\right)\end{array}$ & $\begin{array}{c}\text { Linear dynamic range / } \\
\left(\mu \mathrm{mol} \mathrm{L}^{-1}\right)\end{array}$ & Reference \\
\hline DPV & -1.14 & HMDE & 7.6 & $25.5-122.3$ & 15 \\
DPV & -1.04 & Graphite & 0.36 & $0.41-20$ & 16 \\
SWV & -1.20 & Graphite & 0.06 & $0.07-100$ & 17 \\
SWP & -1.20 & HMDE & 0.003 & $0.009-0.4$ & 22 \\
SWV & +0.90 & MWNT & 0.09 & $0.15-100$ & This work \\
\hline
\end{tabular}

DPV: differential pulse voltammetry; SWV: square wave voltammetry; SWP: square wave polarography; HMDE: hanging mercury drop electrode; CPE: carbon paste electrode; LOD: limit of detection; LDR: linear dynamic range. 
Table 2. Interference study under the optimum conditions

Species

Tolerance limit ${ }^{\mathrm{a}}$

$\mathrm{Na}^{+}, \mathrm{K}^{+}, \mathrm{NO}_{3}^{-}, \mathrm{Ca}^{2+}, \mathrm{Mg}^{2+}, \mathrm{SO}_{4}{ }^{2-}, \mathrm{Cl}^{-}, \mathrm{CO}_{3}{ }^{2-}$, Cortion, Amoxicilin, Methyprednisolone, Phenazopyridine, Isobuthyl phenyl propionicacid $1000^{*}$

DNA, Aminoantipyrene, Chloroamine-T hydrate, Arginine, Valine, Histidine, Tryptophan, Glycine, Cysteine, Glucose, Starch, Cysteic 100 acid, Citric acid, Urea, Uric acid, Tartaric acid, Ascorbic acid, Sacarose

anterference limit concentration of species times than dexamethasone concentration. *Maximum concentration of tested species.

Table 3. Determination of dexamethasone in real sample at $\mathrm{pH} 5.0$ (3 measurements on each sample)

\begin{tabular}{|c|c|c|c|}
\hline No. & DXA added / $\left(\mu \mathrm{mol} \mathrm{L}{ }^{-1}\right)$ & DXA found / $\left(\mu \mathrm{mol} \mathrm{L}{ }^{-1}\right)$ & Recovery / (\%) \\
\hline \multicolumn{4}{|c|}{ Ampoule } \\
\hline 1 & $1.000^{\mathrm{a}}$ & $1.015 \pm 0.010$ & 101.5 \\
\hline 2 & $1.200^{\mathrm{a}}$ & $1.218 \pm 0.012$ & 101.5 \\
\hline \multicolumn{4}{|l|}{ Urine } \\
\hline 1 & 1.000 & $1.027 \pm 0.010$ & 102.7 \\
\hline 2 & 1.200 & $1.235 \pm 0.012$ & 103.0 \\
\hline \multicolumn{4}{|c|}{ Plasma } \\
\hline 1 & 1.000 & $0.999 \pm 0.010$ & 99.9 \\
\hline 2 & 1.200 & $1.191 \pm 0.011$ & 99.3 \\
\hline
\end{tabular}

ampoule content of $1 \mathrm{mg} \mathrm{mL}^{-1}$ of dexamethasone diluted to sufficient concentration.

injection ampoule which are commercial available for dexamethasone, plasma, and urine samples by spiking the samples with standard values of dexamethasone. The standard addition method was used for the analysis. The results are given in Table 3, which indicate that the results are satisfactory for analytical determination of dexamethasone in real samples.

\section{Conclusions}

The electrochemical results discussed above demonstrate the electrochemical response of dexamethasone on the modified pencil electrode. An adsorption process was found to occur during the redox process of dexamethasone on the electrode surface as revealed by impedance measurements. Electrochemical studies for identifying the dexamethasone oxidation mechanism confirmed the contribution of one electron and one proton in the process. It was also shown that the proposed method outperforms the other reported electrochemical methods in analyzing dexamethasone with a satisfactory sensitivity and determination range and with a low experimental detection limit of $0.09 \mu \mathrm{mol} \mathrm{L}^{-1}$. Based on our findings, this modified electrode can be properly used for the determination of dexamethasone in pharmaceutical and urine samples with satisfactory results.

\section{Acknowledgments}

The authors wish to thank Isfahan University of Technology (IUT) Research Council, Center of Excellence in Sensor and Green Chemistry and Nano for supporting of this work.

\section{References}

1. Van de Beek, D.; de Gans, J.; McIntyre, P.; Prasad, K.; Cochrane Database Syst. Rev. 2007, 1, CD004405.

2. Gallego, J. M .L.; Arroyo, J. P.; J. Pharm. Biomed. Anal. 2002, 30,1255 .

3. Grippaa, E.; Santinia, L.; Castellanob, G.; Gattoa, M. T.; Leonea, M. G.; Sasoa, L.; J. Chromatogr., B 2000, 738, 17.

4. Huetos, O.; Ramos, M.; Pozuelo, M. M.; Andr, M. S.; Reuvers, T. B. A.; Analyst 1999, 124, 1583.

5. Wasch, K. D.; Brabander, H. D.; Courtheyn, D. C.; Peteghem, V.; Analyst 1998, 123, 2415.

6. Shibasaki, H.; Furuta, T.; Kasuya, Y; J. Chromatogr., B 1997, $692,7$.

7. Creaser, C. S.; Feely, S. J.; Houghton, E.; Seymour, M.; J. Chromatogr., A 1998, 794, 37.

8. Cherlet, M.; Baere, S. D.; Backer, P. D; J. Chromatogr., B 2004, 805, 57. 
9. Hidalgo, O. H.; Lopez, M. J.; Carazo, E. A.; Larrea, M. S. A.; Reuvers, T. B. A.; J. Chromatogr., B 2003, 788, 137.

10. Iglesias, Y.; Fente, C.; Mayo, S.; Vazquez, B.; Franco, C.; Cepeda, A.; Analyst 2000, 125, 2071.

11. Iglesias, Y.; Fente, C.; Vazquez, B. I.; Franco, C.; Cepeda, A.; Mayo, S.; Anal. Chim. Acta 2002, 468, 43.

12. Toriba, A.; Kubo, H.; J. Liq. Chromatogr. Relat. Technol. 1997, 20, 2965.

13. Niwa, Y.; Somiya, K.; Miyachi, Y.; Kanoh, T.; Sakane, T.; Inflammation 1987, 11, 163.

14. Wu, F.; Lv, J.; Talanta 2007, 72, 1811.

15. Jeyaseelan, C.; Joshi, A. P.; Anal. Bioanal. Chem. 2002, 373, 772 .

16. Balaji, K.; Raghunadha R. G. V.; Madhusudana R. T.; Jayarama R. S.; Afr. J. Pharm. Pharmacol. 2008, 2, 157.
17. Goyal, R. N.; Gupta, V. K.; Chatterjee, S.; Biosens. Bioelectron. 2009, 24, 1649.

18. Rezaei, B.; Mirahmadi Z., S. Z.; Anal. Lett. 2008, 41, 2267.

19. Rezaei, B.; Mirahamdi Z., S. Z.; Sens. Actuators, B 2008, 134 , 292.

20. Nth, M.; Chau, T.; Thwaites, G.; N. Engl. J. Med. 2007, 357, 2431.

21. Quentel, F.; Elleouet, C.; Electroanalysis 2001, 13, 1030.

22. Ghoneim, E. M.; El-Attra, M. A.; Ghoneim, M. M.; J. AOAC Int. 2009, 92, 597. 